\title{
Influence of Credit Management on Financial Performance of Dairy Marketing Cooperatives in Kenya
}

\section{Gitau Beth Njeri}

Department of Agricultural Economics \& Agribusiness, Rongo University, Nairobi, Kenya

Email address:

njerigitau13@gmail.com

\section{To cite this article:}

Gitau Beth Njeri. Influence of Credit Management on Financial Performance of Dairy Marketing Cooperatives in Kenya. International Journal of Accounting, Finance and Risk Management. Vol. 6, No. 1, 2021, pp. 10-15. doi: 10.11648/j.ijafrm.20210601.12

Received: June 13, 2019; Accepted: July 8, 2019; Published: January 28, 2021

\begin{abstract}
Agriculture development is the most critical sector for most Sub-Sahara African countries owing to its significance in food security and employment creation. Dairy cooperative societies are central to sustainable development as they are mainly intended to empower the communities especially in rural areas where agriculture is the main stay. According to United Nations estimates, the cooperative movement has brought 800 million people together globally. Dairy farmers have relied more heavily upon dairy cooperative societies to market their milk than have farmers of any other commodity. However, these cooperative societies are faced with various challenges especially after liberation and most cooperative societies in Kenya are under performing as compared to other cooperative societies in similar regions. However, most of the populations in the major production regions live below a dollar a day. This study sought to determine the influence of credit management on financial performance of Dairy cooperatives in Kisii, Nyamira, Bomet and Kericho Counties, Kenya. The study design is descriptive panel research design. Secondary data was used for analysis. The target population was four dairy marketing cooperatives with a total population of one thousand two hundred and forty five $(1,245)$ dairy farmers registered as at December, 2018 by the Commissioner of cooperatives in Kenya in Kisii, Nyamira, Bomet and Kericho counties which also formed the study target units. Census sampling was used to select sample of the population. Secondary data over the ten yearperiod covering 2009-2018 was obtained. Data was collected using secondary data collection sheet and analyzed using multiple panel regression models. Limitations faced during data collection included high illiteracy levels amongst cooperative members. This was controlled by taking the officials through the facets of credit management to have them understand the concepts under enquiry. The study findings showed that credit management had significant influence on return on investment, a measure of financial performance of dairy marketing cooperatives in Kenya and tests for significance also showed that the influence was statistically significant. The study therefore recommends that all dairy marketing cooperative officials and members be trained on credit management aspects.
\end{abstract}

Keywords: Credit Management, Financial Management, Dairy Marketing Cooperative Societies

\section{Introduction}

In United State of America, dairy cooperative societies were among the first type of agricultural cooperative societies to be organized and they have their beginning in the early 1800 s, [8]. Dairy cooperative societies have played a very significant role in the procurement, processing and marketing of milk and dairy products and in representing farmers politically at both the state and national level.

In Africa Cooperative development is phased into two eras, the post-independence 1960's to $1980 \mathrm{~s}$ and liberalisation era in early 1990's. In both phases, legal frameworks gave African governments powers to direct and manage the affairs of the cooperative societies, which enjoyed monopolies in trade, were rarely truly voluntary, autonomous or independent. They were subsequently engulfed into state politics [12].

In Kenya, the first Co-operative Society, Lumbwa Cooperative Society, was formed in 1908 by the European Farmers with the main objective of purchasing fertilizer, chemicals, seeds and other farm input and then markets their produce to take advantage of economies of scale. The African smallholder farmers fought for formation of their own Cooperative societies and later the dairy cooperative 
society was formed in 1928 in Nanyuki known as Nanyuki Cooperative Creameries and later an enactment of the Kenya Cooperative Ordinance of 1930 leading to the registration of KCC and KFA in 1931. In 1931 all the cooperative creameries were united under the Kenya Cooperative Creameries. In 1950s they were allowed to promote and register Co-operatives for cash crops like coffee and pyrethrum. Consequently at independence in 1963, there were 1,030 Co-operative Societies with 655 being active with a total membership of 355,000, [20].

\subsection{Dairy Production in Kenya}

In Kenya, the dairy industry is the single largest agricultural sub-sector and it contributes to 14 percent of agricultural Gross Domestic Product (GDP) and 3.5 percent of total GDP, [20]. The Ministry of Livestock Development estimates the total annual milk production in the country at 3.5 billion liters [20], translating to an average yield per cow at 564 kilograms per year for both indigenous and grade cows and 1500 kilograms for grade cows. Though the dairy industry has been growing, after years of decline and disruption by liberalization, Kenya's yields remain significantly below international standards; South Africa and Argentina have yields ranging between 2,500 and 3,500 kilograms per year, while the USA stands at an average of 9,000 kilograms per year. With all this challenges, some dairy cooperative societies have flourished and expanded their services to value addition and there by becoming a major player in Kenya such as Githunguri Dairy Cooperative society in Kiambu County, Kenya, [34].

\subsection{Working Capital Management in the Agriculture Sector}

As established by several researchers ([24, 25, 14]) efficient management of working capital is critical to the health and performance of small firms hence their view that firms should employ the use of efficient working capital management practices as a strategy of improving their value. The investigation on the working capital management by the agriculture sector in this study is focused on credit management.

Businesses normally use trade credit as a marketing strategy to expand or maintain sales [24]. Efficient debt management augmented by a shortened creditor's collection period, low levels of bad debts and a sound credit policy often improves the businesses' ability to attract new customers and accordingly increase financial performance. There is therefore need for a sound credit policy that will ensure that agricultural enterprises' value is optimized [28]. Costs of cash discounts, losses of bad debts and costs of managing credit and credit collections constitute the carrying costs associated with granting a credit which increase when the amount of receivables granted are increased. Lost sales resulting from not granting credit constitute the opportunity cost which decrease when the amounts of receivables are increased. Firms that are efficient in receivables management should determine their optimal credit which minimizes the total costs of granting credit [28].

A study by [18] observed that an increase in the level of accounts receivables in a firm increases both the net working capital and the costs of holding and managing accounts receivables and both lead to a decrease in the value of the firm. A study by [31] affirmed that putting in place a sound credit policy ensures proper debt collection procedures and is pivotal in improving efficiency in receivables management hence the performance of firms.

\subsection{Statement of the Problem}

Milk production in Kenya is predominantly produced by small scale farmers $(625,000)$ who own one to three dairy animals, and produce about 80 percent of the milk in the country and market their milk mainly through dairy cooperative societies. Dairy production offers regular income and asset accumulation to families, thereby contributing to Millennium Development Goal one of poverty reduction through the economic growth and wealth creation. [2] states that for a business firm to be able to sustain its business operations and meet its goals and objectives it must manage its working capital effectively and prudently. The dairy business in Kenya is not an exception to this regard.

Besides, despite the high government of Kenya support to the agriculture sector and specifically dairy farming, much documented evidence still report failure in the sector. However, the dairy cooperative societies have faced various challenges especially after liberation and most of the cooperative societies are not performing well. According to [17], factors that could influence poor performance of cooperative societies particularly in the liberation era include lack of training and unpreparedness by cooperative societies to modernize and embrace change, poor marketing strategies and competition from other stakeholders, lack of essential services and poor management and leadership since majority of cooperative leaders are either illiterate or with low education levels, exposure and trainings. In addition, mismanagement and corruption could also influences performance of dairy cooperative societies in Kenya. It is therefore of great importance to determine what the farmers or their advices are not doing right. Therefore, this study evaluated the effect of credit management on the performance of the dairy marketers in Kenya.

\subsection{Objectives of the Study}

The main objective of the study was to analyze the effect of working capital management on financial performance of dairy marketing cooperative societies in Kenya. The specific objective was to establish the effect of credit management on financial performance of dairy marketing cooperative societies in Kenya.

\subsection{Research Hypothesis}

H0: There is no significant effect of credit management on financial performance of dairy marketing co-operatives in 
Kenya.

\section{Theoretical Framework}

\subsection{Financial Stewardship Theory}

A study by [34] found that co-operative autonomy was associated with success; governance structures need to be strong, transparent and honest a requirement in debt management; co-operatives needed to perform well to survive, endure and thrive; and support to co-operative development that creates dependency undermined the mutual self-reliance that is central to cooperation. The study recommendation was that co-operatives needed to develop professional management in order to adapt, innovate, and take rational risks to satisfy the expectations of their owners; and co-operatives succeeded when they consistently delivered value to their owners. The study by USAID very well showed the need for good stewardship and the need to deliver effectively and hence is applicable in this current study. Stewardship theory is relevant to this study because it sought to determine the extent to which credit management drive working capital management in enhancing performance of dairy business.

Conceptual Framework

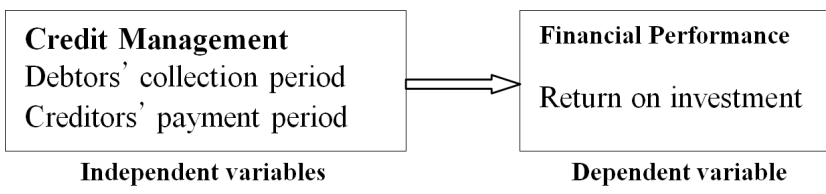

Figure 1. Conceptual Framework.

\subsection{Financial Performance}

Financial performance is a measure of how well a firm can use assets from its primary mode of business and generate revenues. This term is also used as a general measure of a firm's overall financial health over a given period of time, and can be used to compare similar firms across the same industry or to compare industries or sectors in aggregation. There are many different ways to measure financial performance, but all measures should be taken in aggregation. Line items such as revenue from operations, operating income or cash flow from operations can be used, as well as total unit sales [5].

Both tangible and intangible assets are perceived as potential strategic assets. Among the invisible assets, working capital management are generally considered to be a vital strategic asset. According to [28] working capital management refer to the specific and valuable knowledge that belongs to organization. Consistent with [29] this qualification of working management as a strategic asset rests on a potential link between working capital management on the one side and the firm performance on the other. Further, scholars $([3,18])$ argue that in comparison with the tangible resources, the working capital management or intangible resources are more likely to be the key resources for many enterprises which help them in acquiring the required competitive advantage or to ensure market dominance. Conclusions further reached by $([27,8,32])$ that working capital management could have positive effect on the company's financial performance.

\subsection{Debt Management}

Debt can either be short-term or long-term. Short-term debt represents funds needed to finance the daily operations of the firm, such as trade receivables, short-term loans and inventory financing. These types of fund repayment schedules take place in less than one year. Short-term loans are one of the most common ways for treasurers to finance a firms working capital needs. Usually it is used to finance build-ups of inventory and receivables. [17] further assert that there are also other forms of short term debt such as bankers' acceptance, letter of credit and reverse purchase agreement all of which includes the banks guarantee of payment.

Long-term financing is usually acquired when firms purchase assets such as buildings, equipment or machinery. [30] Averred that even if a firm suffers financially and is not able to make the scheduled payments, they still have an obligation towards the debt providers. The scheduled repayments for these funds extend over periods longer than one year [36]. For companies in need of additional working capital, trade credit can serve as a liquidity reserve. This is credit which is connected to one of the company's account and usually, according to [15] company pays a yearly fee for the use of a trade credit and interest can be charged quarterly. What they observed is that when interest is charged quarterly it gives an interest effect which can become very expensive for the company. Other options should therefore be explored as means for short-term financing which offer lower costs for the firm.

\section{Methodology}

\subsection{Research Design}

The study used panel descriptive research design. Panel descriptive research design applied on secondary data involved collecting and analyzing data from cooperative societies over a period of ten years (2009-2018) where it was constituted and analyzed in form of panels.

\subsection{Target Population}

This study focused on dairy enterprises registered as marketing cooperative societies by the commissioner of cooperatives in Kenya as at 31 st December 2018. The study targeted farmers who are members of the four (4) dairy marketing cooperatives with a total population of 1,245 dairy farmers (MOA, 2018).

\subsection{Sample and Sampling Procedure}

The criteria adopted in selection of the sample for this 
study was that the dairy marketing cooperative must be registered with the commissioner of cooperatives as at December 2018. Multistage and purposive sampling was used. All the four marketing cooperatives in the four counties in Kenya were sampled.

\subsection{Data Collection Procedure}

Secondary data was obtained from the review of audited financial statements of the cooperative societies over the 10-year period from 2009 to 2018 (both years inclusive). The data collected aided in computation of inventory holding period as measures of credit management as well as return on investment as the financial performance indicator. Therefore, dairy marketing cooperatives' audited financial statements were reviewed.

\subsection{Data Analysis}

Secondary data collected on inventory holding period from the audited financial statements of the four cooperative societies during the period 2009-2018 was analyzed using Panel Multiple Regression analysis to test the statistical relationships and significance of credit management on the dependent variable (financial performance as measured by return on investment). A panel data set is one that follows a given sample of individuals over time and thus provides multiple observations of each individual in the sample. The choice of panel regression was informed by and in line with [1] who observed that Panel data enables the researcher to control for unobserved heterogeneity, and secondly since panel data have both cross-sectional and time series dimensions, it provides the researcher with sufficient data points to reduce the likelihood of biasness in the parameter estimators.

The general pooled regression model is specified by:

$$
\text { Yit }=\beta 1+\beta 2 \mathrm{X} 2 \mathrm{it}++\mathrm{Uit}
$$

Where;

Yit is the predicted, Xit is the vector of predictor variables, $\beta 1$ is the coefficient of the predictor variable, $i$ refers to the firm and $t$ refers to the time

\section{Findings and Discussion}

\subsection{Panel Regression Analysis}

\section{Credit management}

The objective of this analysis was to find out if there exists a relationship between average collection period (independent variable) and financial performance (dependent variable) and to this extent, the linear regression analysis which shows the relationship between the dependent variable which is financial performance as measured by ROI and independent variable which is average collection period practice is used. For this variable, the regression model is summarized in Table 1.

Table 1. Regression Coefficients -Credit management and ROI.

\begin{tabular}{lllll}
\hline \multirow{2}{*}{ Model } & Unstandardized Coefficients & Standardized Coefficients & Beta & S \\
\cline { 2 - 5 } & B & Std. Error & & \\
\hline Constant & 12.48 & .957 & .657 & 13.050 \\
ACP & 0.535 & .031 & .000 & 17.422 \\
\hline
\end{tabular}

Using the summary presented in Table 1 a linear regression model of the form

$$
\begin{gathered}
\mathrm{Y}=\alpha+\beta \mathrm{Xi} \text { can be fitted as follows: } \\
\mathrm{Y}=12.489+0.535 \mathrm{Xi}
\end{gathered}
$$

The results indicate that $1 \%$ change in average collection period leads to $53.5 \%$ increase in return on amounts invested hence cannot be ignored. A study by [11] emphasized that firms can create value by reducing the number of days of accounts receivable, thus confirming the finding of [9] who established that the length of receivables collection period has a negative effect on a firm's performance. Accordingly, study by [31] also affirmed that putting in place a sound credit policy ensures proper debt collection procedures and is pivotal in improving efficiency in receivables management hence the performance of firms.

Table 2. Model summary-Credit Management with ROI.

\begin{tabular}{llll}
\hline $\mathbf{R}$ & R Square & Adjusted R Square & Std. Error of the Estimate \\
\hline .657 & .431 & .430 & 4.12179 \\
\hline
\end{tabular}

Table 2 presents the coefficient of determination $\mathrm{R}$ squared is 0.430 and $\mathrm{r}$ is 0.657 at 0.05 significance level. The coefficient of determination indicates that $43.0 \%$ of the variation in return on amounts invested as a measure of performance can be explained to by credit management. The correlation coefficient $r=0.657$ implies that there exists a positive significant relationship between credit management and ROI.

Table 3. ANOVA - Credit management and ROI.

\begin{tabular}{llllll}
\hline Indicator & Sum of squares & df & Mean Square & F & Sig. \\
\hline Regression & & 1 & 5156.467 & 303.516 \\
Residual & 48.267 & 298 & 16.9 & \\
Total & 118.826 & 299 & & \\
\hline
\end{tabular}


Table 3 shows that credit management with ROI have the F-statistic of 303.516 and P-value is 0.00 which is less than 0.05. Results indicate that there is no significant mean difference of credit management with ROI. This implies that the model in use was significantly fit and can be used to make predictions. As we reject the null hypothesis $\mathrm{H} 0$ : $\mathrm{b} 0=\mathrm{b} 1=0$ and conclude that at least one coefficient of the model is greater than zero. The meaning of this result is that credit management as a variable in this study cannot be ignored when explaining the factors that have an influence on ROI. In fact, credit management is therefore a significant variable that must be taken into account when studying the financial performance of dairy marketers, further confirming research findings by [31] that putting in place a sound credit policy ensures proper debt collection procedures and is pivotal in improving efficiency in receivables management hence the performance of firms.

\subsection{Hypothesis Testing Results}

The analysis results of secondary data show that credit management has significant effect on financial performance of dairy marketing cooperatives at $5 \%$ level. This is evidenced by the $p$-values corresponding to the coefficients of debt management variable $(p=0.0000, p=0.0000$ and $p=0.0000)$. This finding led the study to reject the stated null hypothesis with $95 \%$ confidence level. By rejecting the null hypothesis, the study accepted the alternative hypothesis that credit management has significant effect on financial performance of dairy marketing cooperative societies in Kenya.

\section{Summary of the Findings}

The first objective of the study was set to establish the influence of credit management on performance of dairy marketing cooperatives in Kenya. The findings revealed that credit management has a positive influence on the performance of dairy marketing cooperatives in Kenya. This finding is supported by the coefficient of determination which shows that the variations in ROI are explained by credit management. The influence of credit management on performance as measured by ROI is also statistically significant and hence the alternate hypothesis was accepted. This means that the influence is not by chance. Dairy marketing cooperatives have been using credit management practice to grow their businesses and subsequently their ROI.

\subsection{Conclusion}

Based on the study findings, it can be concluded that credit management affect performance of dairy farmers in Kenya positively. The adoption of the credit management by the dairy farmers has a high potential of improving performance and hence better returns to the farmers. The formation of cooperative societies has made the adoption rate to be high among the cooperative society officials though farmers need to be sensitized more on the need to adopt fully the management of credit. Dairy farming has continued to perform well even when production of other sectors has been declined over the years. This can be explained by the adoption of management of credit which has enabled cooperatives to realize enhanced returns for its members as compared to traditional means of selling at the farm gate prices to middle men.

It should also be noted that the performance of dairy marketing cooperatives is not purely and wholly derived from the management of credit because there are other drivers of performance in the farming sector.

\subsection{Recommendations}

Dairy marketing cooperatives should continue investing more on training of both cooperative officials and farmers on the need for credit management as compared to avoiding use of debt to fund the enterprises. The amounts of transaction that can be made by investing more funds into the farming venture accompanied by prudent management of credit can be tremendous resulting to higher returns. This helps in increasing volume of sales hence returns both locally and in the international markets where demand for dairy products is currently not being met. Dairy marketing cooperative societies should explore more ways of being funded to expand on their current levels of operations.

This study did not include all farming enterprises in Kenya. A detailed study can be conducted to establish the effects of adoption of credit management on other farming enterprises and especially those in large production.

\section{References}

[1] Baltagi, B. H., Bratberg, E., \& Holmås, T. H. (2005). A panel data study of physicians' labor supply: The case of Norway. Health Economics, 14 (10), 1035-1045.

[2] Bhattacharya, H. (2006). Working Capital Management: Strategies and Techniques. New Delhi, Prentice Hall.

[3] Brennan, N. and Connell, B. (2000), "Intellectual capital: Current issues and policy implications", Journal of Intellectual Capital, Vol. 1, No. 3, pp. 206-240.

[4] Bryman, A., \& Bell, E. (2003). Business Research Methods. UK: Oxford University Press.

[5] Business Dictionary. (2011). Online website resource available at http://www.businessdictionary.com Retrieved on 20th July 2015.

[6] Central Bureau of Statistics. (2003). Geographic Dimensions of Well-Being in Kenya (Regal Press Kenya, Nairobi, Kenya), Vol 1.

[7] Cohen, J., Cohen, P., West, S. G., \& Aiken, L. S. (2003). Applied Multiple Regression/Correlation Analysis for the Behavioral Sciences (3rd edition). Mahwah, NJ: Erlbaum.

[8] Cropp, B, and Graf T., (2001). The History and Role of Dairy Cooperatives. Iowa State University Press, Iowa. 
[9] Deloof, M. (2003). Does Working Capital Management Affect Profitability of Belgian Firms? J. Bus. Financial Account. 30 (314): 573-587.

[10] Gall, M. D., Borg, W. R., \& Gall, J. P. (2008). Education research: An introduction (8th ed.). New York: Pearson publishers.

[11] Juan, P. G, Martinez, S. (2002). Effects of working capital management on SME profitability, Retrieved from http://www.sagepublicationson5th Feb 2010, J. Bus. Financ. Account., 30 (3-4): 1-14.

[12] Karanja, A. M., (2003). The Dairy Industry In Kenya: The PostLiberalisation Agenda. Paper presented at a dairy industry stakeholders workshop in Nairobi (27th August 2002).

[13] Kokech, T. (2009). The Grassroots Alliance for Community Education, a Community Based Organization (CBO) Report. Available at $<$ http://www.graceusa.org/Kokech/index.php>, accessed on 4th August, 2015).

[14] Kotut, P. K. (2003). Working capital management practices by Kenyan firms: A case study of firms listed in the NSE. Unpublished MBA project. Egerton University.

[15] Larsson, C-G. \& Hammarlund, L. F. (2007). Cash Management för företag. 9th ed. Student litteratur, Lund.

[16] Lucas, S. \& Timmer, P. (2005). Connecting the Poor to Economic Growth: Eight Key questions. Centre for Global Development.

[17] Manness, W. \& Zietlow, E. (2005). Dairy Farm Management and Long - Term Farm Financial Performance. Agricultural and Resource Economics Review, 31: 233-247.

[18] Marr, E. (2004). Capital Structure, Firm Size, and Efficiency: The Case of Farm Petroleum and Animal Feed Co-operatives in Canada. Agricultural Finance Review.

[19] Michalski, G. M. (2007). Small and Medium Enterprises Accounts Receivable Management with Value of Liquidity in View. Available at http://ssrn.com.

[20] Ministry of Cooperative Development and Marketing (2008). Cooperative Development Policy, (2008). Government Printers, Nairobi.

[21] Omore, A. and Staal, S. (eds.) (1998). The Tanzania Dairy Sub-Sector: A Rapid Appraisal. Vol. 3 - Main Report. ILRI (International Livestock Research Institute), Nairobi.

[22] Orodho, J. A. (2003). Essentials of educational and Social Sciences Research Methods. Nairobi.

[23] Owango, M. O., Staal, J. S., Kenyanjui, M., Lukuyu, B., Njubi, D. and Thorpe, W. (1998). Dairy cooperatives and policy reform in Kenya: effects of livestock service and milk market liberalisation. Food Policy. 23: 173-185.

[24] Padachi, K. (2006). Trends in Working Capital Management and its Effect on Firms Performance: An Analysis of Mauritian Small Manufacturing Firms". Retrieved from http://www.emeraldinsight.com/ on January 2015. Int. Rev. Bus. Res., 2 (2): 45-58.

[25] Peel, M. \& Wilson, N. (1997). "Working Capital and Financial Management Practices in the Small Firm Sector", Retrieved from http://www.sagepublications.com on $5^{\text {th }}$ February 2015. Int. Small. Bus. J., 14 (2): 52-68.

[26] Pandey, I. M. (2005). Financial Management $9^{\text {th }}$ Edition, Vikas Publishing House PVT Ltd.

[27] Riahi-Belkaoui, A. (2003). Intellectual Capital and Firm Performance of US Multinational Firms: A Study of the Resource-based and Stakeholder Views, Journal of Intellectual Capital, 4 (2), pp. 215-226.

[28] Ross, S. A., Westerfield, R. W. \& Jordan, B. D. (2008). Fundamentals of Corporate Finance, New York: McGraw-Hill Companies Inc.

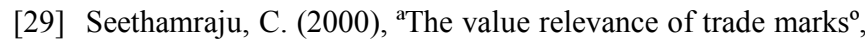
$\mathrm{PhD}$ dissertation, New York University, New York, NY.

[30] Shah, A. \& Hijazi, T. (2004). The determinants of capital structure of stock exchange listed non-financial firms in Pakistan. The Pakistan Development Review, 43 (4): 605-618.

[31] Sushma, V. \& Bhubesh, S. (2007). Effect of working capital management policies on corporate performance an empirical study. Global Business Review, 8, 267.

[32] Tan, R. \& Timmy, G. (2007). A Comparative Study of the Financial Problems Faced by Micro, small and medium Enterprises in the Manufacturing sector of Fiji and Tham.

[33] Thirtle, C., Irz, X., Lin, L., McKenzie-Hill, V. \& Wiggins, S. (2001). Relationship between changes in agricultural productivity and the incidence of poverty in developing countries. DFID Report.

[34] USAID. (2001). Report to congress on the implementation of the support for overseas co-operative development act. Washington: USAID.

[35] Wanyama, F. O. (2008). The Qualitative and Quantitative Growth of the Cooperative Movement in Kenya. International Labour Office, Geneva.

[36] Zietlow, J. Hankin, J. \& Seidner, A. (2007). Financial management for non-profit organizations: Policies and practices. Hoboken, NJ: Wileys. 